\title{
Wstęp
}

\section{Wyobraźnia antynomiczna}

Jakub Momro

TEKSTY DRUGIE 2018, NR 5, S. 7-24

DOI: $10.18318 /$ td.2018.5.1

Całkiem inaczej rzecz ma się z tymi tworami wyobraźni, wobec których nikt nie może zająć stanowiska ani dać ich zrozumiałego pojęcia. Są to jakby monogramy, jedynie poszczególne rysy, nieokreślone przez żadne dające się podać prawidło, które są raczej rysunkiem, jakby wahającym się pośrodku między różnymi doświadczeniami, niż określonym obrazem.

Immanuel Kant

Załóżmy jednak, że spoglądamy w otchłań.

Peter Frase

Wyobraźnia martwa wyobraźcie sobie.

Samuel Beckett

\section{1.}

Zacznę od ostatniego epigrafu. Sądzę bowiem, że sformułowanie Becketta, będące incipitem jednej z jego krótkich próz', doskonale opisuje brak widoczny $w$ dzisiejszych naukach
Jakub Momro (1979)

- filozof, literaturoznawca, eseista i tłumacz. Adiunkt w Katedrze Antropologii Literatury i Badań Kulturowych na Wydziale Polonistyki UJ. Członek redakcji „Tekstów Drugich", Rady Redakcyjnej serii wydawniczej "Nowa Humanistyka". Ostatnio opublikował Widmontologie nowoczesności. Genezy, Warszawa 2014. W przygotowaniu książka: „Ucho nie ma powieki."Dźwiękowe sceny pierwotne.

1 Por. S. Beckett Wyobraźnia martwa wyobraźcie sobie, przeł. A. Libera, w: tegoż, Pisma prozą, przeł. A. Libera, P. Kamiński, Czytelnik, Warszawa 1982. 
humanistycznych. Ten brak dotyczy w głównej mierze wyobraźni poznawczej, tzn. wyobraźni jako źródła teoretycznych i analitycznych pomysłów. Beckett, pisząc swój tekst po wydarzeniu-cezurze nowoczesności, czyli po Zagładzie ${ }^{2}$, uzależnił nośność imperatywu "wyobrażania sobie” od śmierci pewnych form estetycznej i społecznej wyobraźni. Opisywany przez niego stan polega jednak nie tylko na archiwizacji dawnych imaginariów, lecz również na tym, że ich współczesny kształt wynika z ciągłego napięcia między determinizmem i wolnością, równoczesnym wyczerpaniem modalności wyobraźni i koniecznością inwencji jej nowych form. Eliptyczne i quasi-normatywne hasło Becketta pełni w gruncie rzeczy funkcję poznawczą i egzystencjalną. „Wyobraźcie sobie" - oto możliwe hasło "nowej humanistyki".

\section{2.}

Epigraf drugi. Peter Frase, jeden z najciekawszych dziś krytyków społecznych i teoretyków ekonomii, szukając sposobu na pokrycie deficytu wyobraźni społecznej, używa formuły, która brzmi tyleż groźnie, co ironicznie. Groźnie - dlatego, że pokusa nihilizmu, owego "spojrzenia w otchłań", od którego można zacząć myśleć od zera, wciąż nie podlega falsyfikacji, lecz raz po raz nawiedza ponadstuletnią tradycję teorii krytycznej niczym „złośliwy demon". Ironicznie - dlatego, że to nihilistyczne monstrum nowoczesności nie chce zejść ze sceny historycznych zdarzeń, a im bardziej jest negowane, tym uporczywiej straszy. Ale o jakiej nowoczesności tutaj mowa? Z pewnością nie chodzi o oświeceniowy i bezwzględnie progresywny rozum, który niczym bezosobowa machina zabija wszystko, co nie pasuje do wzorca jednotorowej i powszechnej emancypacji. Toteż awers tej zasady nieskrępowanej wolności rozumu to antymodernizm pojmowany jako reakcja na impulsy oświeceniowe. Stanowi on raczej intrygujący w swej historycznej powtarzalności mechanizm polityczny niż jest faktyczną kontrpropozycją dla projektu oświecenia ${ }^{3}$. Wydaje się zatem, że tym, co w dzisiejszej humanistyce nie

2 Jak ważna poznawczo dla współczesności jest kategoria wyobraźni widać w kuratorskim tekście Georges'a Didi-Hubermana, analizującego fotografie zrobione przez Sonderkommando w Auschwitz. Szkic ten wywołał gwałtowne polemiki, głównie Claude'a Lanzmanna i Gérarda Wajcmana dotyczące ontologicznego statusu obrazów, dokumentu, świadczenia, historii po Zagładzie oraz granicy między współczesnym ikonoklazmem a idolatrią. Por. G. Didi-Huberman Obrazy mimo wszystko, przeł. Mai Kubiak Ho-Chi, Universitas, Kraków 2012.

3 Por. A. Compagnon Les Antimodernes. de Joseph de Maistre à Roland Barthes, Gallimard, Paris 2005. Compagnon uosabia klasyczny przykład ideologii jako mistyfikacji i „złej wiary”, przez co każdy z bohaterów jego książki: od reakcjonistów po progresistów nie jest w istocie tym, za kogo się podaje, albo o którym świadczy jego praktyka intelektualna. Tymczasem jak de Maistre ostatecznie jest przeciwnikiem oświecenia, tak Barthes jest podejrzliwym zwolennikiem estetycznej modernizacji. 
chce umrzeć i powraca raz po raz jako widmo, to nie nowoczesność w ogóle, ów słabo określony, pozornie uniwersalny "duch czasów", lecz nowoczesność w swym wymiarze radykalnym, a więc dialektycznym.

To właśnie myślenie o świecie, kulturze, języku i polityce w kategoriach różnych form sprzeczności wydaje się dziś pokątnie powracać (np.: w studiach Georges'a Didi-Hubermana, pracach Alexandra Klugego, utworach Heinera Goebbelsa, praktyce choreograficznej Mathilde Monnier czy projekcie „Szkoły Słoweńskiej”). Antynomie, aporie, nierozstrzygalności nie są już dziś wszelako docelową stacją procesu refleksji, lecz efektem „założonej wiedzy” - sprzeczność to moment i punkt (czas i miejsce), od którego rozpoczyna się pojęciowa i materialna aktywność podmiotów. I choć z pozoru brzmi to banalnie, różne wcielenia dialektycznej nowoczesności pokazują, że rzeczywistość właśnie dlatego, że jest nieredukowalnie sprzeczna, może być prawdziwa. Trywialne nie są z pewnością użytki, jakie z tego prostego rozpoznania możemy zrobić. Gdyby prześledzić (co pokrótce i na kilku zaledwie przykładach staram się zrobić w niniejszym tekście) wzloty i upadki dialektycznych pomysłów w ciągu ostatnich kilkudziesięciu lat, to widać wyraźnie, że losy te pokazują dwie prawidłowości. Pierwszą z nich można opisać jako historyczność myślenia, widoczną w czasowym charakterze pojęć. Drugą - jako zasadę zapośredniczenia, leżącą u podstaw nieredukcyjnego ujęcia podmiotu i poznania. Innymi słowy, dialektyka nie jest "nieżyciową" spekulacją, która oddziela nas od autentycznych i bezpośrednich przeżyć, lecz krytycznym doświadczeniem świadomości, w którym mentalny obraz i ciało, podmiot i historia, słowo i pojęcie, afekt i język wchodzą ze sobą w kolizję.

Rzecz jasna, tak rozumianej nowoczesności dialektycznej nie sposób obronić z punktu widzenia nowych teorii humanistycznych. Dość spojrzeć na twórczość Bruno Latoura, dla którego sam akt założycielski modernizacji jest fantazmatem, wyrosłym na wolności spekulatywnej, przerafinowanej, mającej mało wspólnego z systemami nauki, z prawami dowodzenia i potencjalną odkrywczością eksperymentu. Właściwie od pierwszych prac o Pasteurze, przez bardzo ważną książkę-dialog z Michelem Serres'em", aż do quasi-manifestu Nigdy nie byliśmy nowocześni Latour, pragnąc wydostać się z archaicznego podziału na podmiot i przedmiot, a także chcąc zbudować sieciowy model tworzenia i społeczno-polityczny model legitymizacji nauki, z konieczności unieważnia wspomnianą wyżej podstawową zasadę dialektyki nowoczesnej, czyli mediatyzację. I choć jego własna koncepcja medium oraz pojęciowej idealizacji jest fascynująca, to odrzucenie „konstytucji nowoczesności” opiera się na całkowitym - i bodaj celowo świadomym - uchyleniu elementarnych założeń tejże „konstytucji."Latour jest pod tym

4 Por. odpowiednio: B. Latour Pasteur. Bataille contre les microbes, Nathan, Paris 1985; M. Serres, B. Latour Éclaircissements, Flammarion, Paris 1992. 
względem symptomatycznym przykładem apologii "nowego początku” w nauce (i jej opisie). Z uporem godnym lepszej sprawy wpisuje fantazje modernistów w schemat całkowitej alienacji (czy istnieje większa obelga dla myśliciela nowoczesnego?), czyli oddzielenia: natury od kultury, natury od społeczeństwa, "pracy” puryfikacji od "pracy” mediatyzacji5. Posunięcie Latoura wydaje się dość jasne z perspektywy jego własnej strategii dyskursywnej, ale w istocie pozwala zobaczyć, że to właśnie jego koncepcja opiera się na walce - via negativa - z Bogiem urojonym nowoczesności. Aby zrozumieć tę walkę z chimerami modernizacji, wystarczy zestawić zasadniczą tezę Latoura o nieuchronnie dualistycznym obrazie świata nowoczesnych z dwoma kluczowymi dla zrozumienia tradycji dialektycznej studiami, pochodzącymi z różnych czasów: Historię iświadomość klasową Lukácsa oraz Postmodernizm, czyli logikę kulturową późnego kapitalizmu Jamesona. Widać w tych dziełach dwa dążenia, które i dziś wydają się ważne: do wypracowania praktyki myślenia, tzn. myślenia, które nie jest autonomiczną refleksją, ale staje się społeczną praxis, wymierzoną w różne formy urzeczowienia życia (Lukács), oraz do łącznego myślenia o materialności kultury, warunkach społecznych i realności gestów emancypacyjnych w sytuacji rzekomego "końca wielkich narracji” (Jameson) Jak nietrudno zauważyć, dyskurs Latoura to tour de force współczesnego persyflażu naukowego. Trudno jednak odgadnąć, co kryje się za marzeniami „o nowych słowach, powołujących nowe zgromadzenie", o których Latour pisze na ostatniej stronie swej książki. Lekceważone przez francuskiego uczonego lęki nowoczesnych przeobrażają się w jego przypadku w fantazję o życiu i myśleniu, które byłoby wyzbyte całkowicie myślenia krytycznego.

Ujmując to inaczej: im silniejsza potrzeba epistemologicznej, politycznej, społecznej, a także estetycznej zmiany, tym mocniejsze przywiązanie do niezbywalnej modernizacyjnej idei przekroczenia, która za oczywistego przeciwnika wybierała tendencje antyoświeceniowe, za mniej oczywistego - samą siebie, tzn. pozorną oczywistość własnych praktyk i dyskursów. Dziś z pewnością nie chodzi w ogóle o restytucję starych sporów o granice formacji społeczno-kulturowych ani także (jak było w przypadku historycznie niezbędnej, ale dziś zupełnie martwej debaty o status ponowoczesności) o rodzaj wewnętrznej korekty, jaką aktorzy świata nowoczesnego chcieli przeprowadzić, aby pole historii zostało oczyszczone raz na zawsze. Chodzi raczej o pomyślenie historii anachronicznej, w której w „krótkim spięciu” łączą się niejednorodne materie

5 Por. B. Latour Nigdy nie byliśmy nowocześni. Studium z antropologii symetrycznej, przeł. M. Gdula, Oficyna Naukowa, Warszawa 2011, zwł. rozdz. 2: Konstytucja.

6 Por. G. Lukács Historia i świadomość klasowa. Studia o marksistowskiej dialektyce, przeł. i przedm. M.J. Siemek, PWN, Warszawa 1988, F. Jameson Postmodernizm, czyli logika kulturowa późnego kapitalizmu, WU), przeł. M. Płaza, Kraków 2011. 
przeszłości i teraźniejszości, oraz potraktowanie historii jako habitusu, w którym krytyczne prawo rozumu jest nieoddzielne od działania nieświadomości, a teoretyczne projekty zmiany rzeczywistości są filtrowane przez doświadczenia zmysłowe czy ogólniej: empiryczne.

\section{3.}

Epigraf pierwszy. Nikt przed Kantem, ale i po nim, nie połączył w tak intrygujący sposób wyobraźni z myśleniem, w tym przede wszystkim: z myśleniem o tym, co jeszcze lub co już nie jest usankcjonowane wiedzą pewną, co stanowi zaledwie zarys przyszłości albo uporczywy powidok przeszłości. Opisywana przez Kanta sytuacja to moment, w którym jeszcze nie wiadomo, co narodzi się z myślenia, jakie pojęcie czy obraz zawładną naszą percepcją i jak wpłyną one na rozumienie rzeczywistości. To chwila, w której panuje wielość podmiotowych doświadczeń i wrażeń, mnogość stanów świata, jeszcze nieograniczonych krytycznym rozumem.

Intrygująco w tym kontekście wyglądają powstające od pewnego czasu liczne projekty innego utopizmu, w którym ważniejsza od projektodawczych wizji przyszłości stała się refleksja nad formami historyczności i czasu (ich ograniczeniami lub ich siłą) oraz obrazu ( $w$ formie fantazmatu lub fantazji zbiorowej bądź przeciwnie: obrazu jako formy refleksji). Siłą rzeczy taki afirmatywny wymiar myślenia utopijnego ma swój - mniej lub bardziej perwersyjny - awers w postaci fetysza dystopii. Wszystkie te formuły zapewne sporo mówią o zbiorowych fiksacjach i zakamuflowanych potrzebach (co widać bodaj najpełniej w serialach, których sama formuła zbliża się do skryptu fantazji, tu: znakomita seria Black Mirror), ale przede wszystkim stanowią rodzaj politycznego protokołu wyobraźni. W przypadku tego ostatniego, rzecz jasna, bardzo mocno podejrzanego określenia, chodzi zarówno o - wywiedziony z psychoanalizy i mający wciąż krytyczną, a nie tylko deskryptywną moc - porządek wyobrażeniowego, a więc zestaw scenariuszy fantazji, regresywnych w sferze pragnień, ale nieusuwalnych jako rejestr identyfikacyjnych, najczęściej prymitywnych, potrzeb (desublimacji, odhamowania, interpasywności itd.). Często tego rodzaju strategie uczestnictwa w kulturze symbolicznej mówią więcej o stanie społeczeństwa niż programy naukowych "zwrotów”, bardziej zaklinają rzeczywistość niż ją diagnozują i ostatecznie - znikają w galopującej inflacji „nowych" konceptualizacji.

Chodzi jednak również o wyobraźnię jako pewną moc krytyczną. Jak się zdaje, nie dość się pamięta o fundamentalnej różnicy między fantazją jako źródłem fantazmatów a wyobraźnią pojmowaną jako pewna praxis myślenia. Tak częste dziś powroty do Kanta zdają się jednak nieśmiało o tym przypominać. Zarówno w ostatnich pracach Catherine Malabou, jak i do pewnego stopnia u niektórych realistów spekulatywnych 
przewija się wątek - traktowany pozytywnie lub negatywnie - granicznego charakteru wyobraźni?. Pozornie archaicznie i podręcznikowo brzmiąca dziś formuła „wyobraźni transcendentalnej" prowadzi do samego centrum współczesnych kłopotów - relacji między wiedzą czy nauką a politycznością, między legitymizacją epistemiczną (co i jak można poznać), a światem praktyk społecznych i działań politycznych (jakie są relacje między wiedzą a zmianą społeczną). Projekt Kanta znajdował, rzecz jasna, swe uzasadnienie w ramach całej złożonej architektoniki zasady krytycznej i historii idealizmu, dziś jednak dawne problemy - "wiedzy pewnej" czy "uprawomocnienia" - wracają z całą mocą. Co prawda, nie możemy się wesprzeć na solidnych fundamentach „różnicy krytycznej", usiłując rozdzielić, a następnie złączyć na nowo władze poszczególnych nauk, nie jesteśmy w stanie wyjaśnić sprzężenia zwrotnego, zachodzącego między pojęciowością a światem empirycznym, ale możemy spróbować pomyśleć o w s p ółczes ności jako o -mniejlub bardziej spójnym, mniej lub bardziej przypadkowym - asamblażu obrazów.

Trzeba jednak wyraźnie zaznaczyć, że chodzi o obrazy właśnie w sensie krytycznym, kreślące granice świata, a także otchłanną niemożliwość myślenia o nim. W tym sensie takie podejście nie podlega prawu podziału i dyscyplinowania, które redukuje i zawęża rozumienie oraz analityczną użyteczność kategorii obrazu. Fantazmat, obiekt estetyczny, różne formy wizualności, przedstawienie jako zasady pojęciowości, a także językowa referencja, polityczna reprezentacja, utopijne bądź dystopijne wizje, powtarzalność i unifikacja wizualna popkultury - te wszystkie, by tak rzec, wcielenia obrazu nie tylko nie dają się od siebie oddzielić, ale przede wszystkim domagają się poznawczego otwarcia wyobraźni jako praktyki krytycznej. Chodzi więc o to, by nie lekceważąc świata empirycznego, wprawić pojęcia w ruch, czyli stworzyć z wielości obrazów nową konfigurację świata, nowy kontur rzeczywistości. Zdaje się zatem, że w takim ujęciu kategoria wyobraźni pozwala dostrzec zasadniczą zmianę teoretyczną ostatnich lat, rozpościerającą się między uniwersalizmem politycznym a uniwersalizmem filozoficznym, oraz między wypracowywaniem idei jako - mniej lub bardziej radykalnej - realnej zmiany porządku społecznego, a usankcjonowaniem reguł pojęciowych w ramach poszczególnych systemów wiedzy i obowiązywania ich praw niczym w naukach ścisłych.

Wróćmy w tym kontekście jeszcze na chwilę do Kanta. Jego założenie dotyczące możliwości krytyki (definiującej w istocie nowoczesność) ${ }^{8}$ opierało się na trwałej

7 Por. C. Malabou Avant demain. Épigenèse et rationalité, P.U.F, Paris 2014. M.B. Kacem Algèbre de la tragedie, Léo Scheer, Paris 2014.

8 W sensie historycznym chodzi tu o niezwykle złożoną i bogatą tradycję teorii krytycznej, która czerpie tyleż z dialektycznej wizji historii Hegla, co z Kantowskiej zasady krytyki jako procesu uświadamiania sobie kryzysowego charakteru metafizyki. Dodać trzeba, że zręby systemu Kan- 
obecności granic, a nie, jak zwykło się mówić, dualizmów - poznanie jest wiarygodne tylko wtedy, gdy nie przekracza własnych ograniczeń. Za linią pojęć i - powiedzielibyśmy dzisiaj - dyskursu o tych pojęciach (całej koncepcji architektury myślenia), rozciąga się właśnie świat wyobraźni: to sekret absolutny, czyli intymność czystego obrazu, a więc "schematu transcendentalnego".Wyobraźnia tworzy więc pozycje, z jakich patrzymy na świat, z jakich rozgraniczamy i zestawiamy na nowo przedmioty, w których opisujemy zjawiska i jak próbujemy je zrozumieć. Tak też należy chyba rozumieć słynne określenie Kanta, jakie pojawia się przy tej okazji, czyli Handgriff, zarazem uchwyt i draśnięcie. Z jednej strony dzięki wyobraźni jesteśmy w stanie „pochwycić" coś, co nie podpada pod prawo rozumu ani nie jest wrażeniem czy rzeczą, z drugiej - wyobraźnia nie jest ani matką fantazmatów, ani strukturą nieredukowalnej fikcji, lecz zranieniem, które przywraca obraz życiu. Krytyka czystego rozumu wskazuje, że ten dotkliwy i dotykowy wymiar wyobraźni musi pozostać ukryty w postaci „czystego obrazu wszystkich przedmiotów zmysłów w ogóle, [którym] jest czas" ${ }^{\text {"10. }}$. Praca wyobraźni polega nie na reprezentacji lub uobecnieniu czy odbiciu tego, co niewidzialne w postaci materialnej repliki, nie stanowi także powtórzenia formalnego. Wyobraźnia krytyczna wyznacza granice świata pojęć, ale zarazem zapowiada rzeczywistość metamorfozy, dzięki której wiedza obrazowa staje się procesem ukonkretnienia, owego tak lubianego przez filozofię logiki concresco, zbierania różnych elementów (form, pojęć, materii, ciał) w jednym punkcie i w jednej chwili. Kantowskiego przeświadczenia o „sztuce ukrytej w głębinach duszy ludzkiej” nie da się dłużej utrzymać nie dlatego, że taki pomysł zakłada jakiś rodzaj esencjalizmu, lecz dlatego, że pozbawia mocy wyobraźnię, zatrzymując ją w granicach samego rozumu. Wyobraźnia tworzy światy, ponieważ w krytycznym ruchu odsłania w otaczających nas pozorach i iluzjach (poznawczych, estetycznych, politycznych) konstytutywny niepokój i poruszenie. Chyba tylko przez taki rodzaj ożywienia obrazów można przywrócić dziś wagę znanej maksymy Kanta, że "myśli bez treści naocznej są puste, dane naoczne bez pojęć - ślepe." Obie części tego równania są równie ważne i zmuszają do przemyślenia raz jeszcze owej określającej nas w znacznym stopniu złożonej relacji między pojęciami, wyobraźnią i obrazami, a społeczną praktyką.

towskiego, czyli podział na „rzecz samą w sobie” i zjawisko, ale przede wszystkim na doświadczenie i pojęcie, zostały niemal całkowicie przejęte przez "teorię krytyczną". Widać to zwłaszcza u Benjamina, Adorna i Blocha.

9 O tym nieoczywistym wymiarze myśli krytycznej: por. J. Derrida Le toucher, Jean-Luc Nancy, Galilée, Paris 2000.

10 I. Kant Krytyka czystego rozumu, przeł. R. Ingarden, PWN, Warszawa 1957, t. 1, S. 291 („O schematyzmie czystych pojęć intelektu", A 141). Por. J.-L. Nancy Image et violence, w: tegoż Au fond des images, Galilée, Paris 2003. 
Dogodnym punktem wyjścia wydaje się kategoria antynomii, która - jako się rzekło - tyleż ustanawia wyobraźnię, co ją niweczy. Z tej dynamiki wyrasta w dużej części nasze myślenie o aktualności. Nie da się ukryć, że antynomia to raczej niechciane dziecko nowoczesności, którym nikt się nie chce dziś zająć. Właśnie dlatego, jak sądzę, warto zobaczyć, jak antynomie napędzały zarówno dyskursy, które wprost opierały swoją siłę obowiązywania na tej kategorii, jak i te, w których antytetyczność była marginesem zasadniczej argumentacji. Warto również spojrzeć na ten mechanizm przekroczenia lub podtrzymywania sprzeczności na dwóch przykładach - jednym bardziej, drugim mniej oczywistym.

\section{4.}

W drugiej połowie XX wieku bodaj najsilniej oddziałującym paradygmatem nauk o człowieku była radykalna teoria podejrzeń, uosabiana przez Jacques'a Derridę. Pierwszy ruch, który od początku swojej refleksji wykonuje francuski filozof, to zdecydowane przesunięcie w obrębie metody pojęciowej - wynalazek dekonstrukcji to niemal całkowite odrzucenie hermeneutyki na rzecz takiej analizy, według której systemowość myślenia nie unieważniała jego zdarzeniowego wymiaru. To prymarne posunięcie Derridy w dużym stopniu uwalnia go od przemożnego wpływu Heideggera i jego idei "zwinięcia metafizyki” oraz zainicjowania przezeń projektu określanego mianem „zadania myślenia". Dekonstrukcja pozwala zobaczyć, że filozofia (a w ślad za nią teoria) nie jest błędnym kołem rozumienia i nierozumienia, lecz dyskursem egzystencjalnej samowiedzy i określoną procedurą zarazem krytyki prawdy (w sensie ścisłym chodzi o „filozofowanie młotem", czyli rozbijanie skostniałych banałów tworzących ideologiczną doksę), jak i wyłaniania się jej nowych form. To właśnie z tych przyczyn we wczesnych pracach Derridy, w których odbijała się żmudna, ale i inwencyjna, lektura dzieł filozoficznych i literackich oraz rodziła się nowatorska koncepcja tekstu, spełniała się (w różnym stopniu) wizja nienormatywnej zasady etycznej jako afirmacji inności oraz prawdy jako zdarzenia. Takie rozumienie prawdy to wynik nieustannego starcia historii i polityki, wraz z jej dominującymi strukturami poznania, rzeczywistości i struktur społecznych z tym, co kruche w swej jednostkowości. Innymi słowy, między Pismem i różnicą, w której „techniczna” analiza pism Freuda łączy się z analizą problemu genezy u Husserla oraz z krytyką kategorii Innego u Levinasa, a Widmami Marksa, różnica jest mniejsza, niż się wydaje na pierwszy rzut oka. I w jednym, i w drugim przypadku Derrida wprawia w ruch maszynę dekonstrukcji, traktując ją jako sposób na wypracowanie takiego modelu samowiedzy, który nie opierałby się na świadomości i obecności, lecz na okrężnej drodze polisemii i złożonych mechanizmów kontekstowych uwikłań danego pojęcia. 
Ale w tym wypadku chodzi także o coś więcej: krytyka w postaci dekonstrukcji broni reguły uprawomocnienia, tyle że nie w postaci metadyskursu, lecz w postaci śladu. W tym sensie nie ma różnicy między analizami hieroglifów Artauda, a słabo zarysowanym projektem "mesjańskości" z książki o Marksie - w obu przypadkach dekonstrukcja, dzięki której można ocalić ideał krytyki wobec "tego, co jest" (a więc właśnie obecności i towarzyszącego jej dyskursu), przeobraża się w dialektykę, w której ogólność pojęć (historii, zbawienia, podmiotu, emancypacji, praktyki) służy za kanwę temu, co dopiero ma nadejść, co tkwi jako nieredukowalna realność w pojawiającym się zdarzeniu. Jeśli dekonstrukcja ostatecznie przestaje być dialektyką, to z pewnością dlatego, że - mimo zapewnień jej twórcy - stała się, jako taka, symptomem wyczerpania i myślenia fantazmatycznego czy - mówiąc ściślej - widmowego. W miejsce Heglowskiego Ducha pojawia się idiosynkratyczny fantom, na tyle uniwersalny i wyzbyty konkretności, że bez przeszkód może mediować między wszystkimi epokami i wszelkimi formami życia i śmierci. Innymi słowy, Derrida chcąc za wszelką cenę uniknąć jakiejkolwiek ustabilizowanej formy pojęciowej czy ramy teoretycznej i dyskursywnej, przeobraził dialektyczny ruch krytycznego zniesienia i przepracowania w dogmatyczną oscylację między sprzecznościami.

Spójrzmy w tym kontekście na teksty Derridy o Artaudzie. Zarówno w Teatrze okrucieństwa i „zamknięciu przedstawienia”, jak i w Słowie podszepniętym naczelny problem stanowi pewna węzłowa i paradygmatyczna dla nowoczesności niemożliwość, sprzeczność tkwiąca w projekcie Artauda". Jeśli „okrucieństwo" miało zrewolucjonizować teatr, to dlatego, że gest rewolty wymierzony został w jego instytucjonalne zabezpieczenie rozumiane dosłownie: jako mieszczański, zmienny historycznie i funkcjonalnie system reprezentacji, jak i w sensie szerszym: jako ufundowana na prymacie słowa (czy, jak chce Derrida, logosu) i niepodzielnej obecności (choćby w postaci aktora odgrywającego rolę, wypowiadającego kwestię i po prostu przebywającego na scenie). Okrucieństwo zatem to zniesienie ograniczeń i konwencji w taką formę życia, która nie podlegałaby już redukcji i wcielałaby wszystkie sprzeczności „urządzenia"teatralnego. Ale właśnie owo marzenie o bezpośredniości gestu i akcji tyleż cielesnej i afektywnej, co dramaturgicznej i wykoncypowanej, odsłania własną fantazmatyczną stronę. Artaud pragnie cielesnej obecności, niwelującej, co ważne, dystans między aktorami i widzami, przedmiotem a gestem, która żyłaby poza słowem (a więc poza zapośredniczeniem i poza symboliczną mediacją). Zarazem jednak to pragnienie jest u samych swych podstaw niemożliwe, ponieważ taką formę obecności zagwarantować może jedynie rodzaj „arcyzapośredniczenia”, czyli teatralna scena. W konsekwencji zaprojektowana

11 Por. J. Derrida Teatr okrucieństwa i „zamknięcie przedstawienia”; Słowo podszepnięte, w: tegoż Pismo i różnica, przeł. K. Kłosiński, Aletheia, Warszawa 2004. 
totalność okrucieństwa, a więc takiego stanu-działania, które wprost i natychmiast inkarnuje się w świecie, staje się kolejnym scenariuszem fantazji o nieskończonej jednostkowości zdarzenia, wokół którego organizują się pojęcia i różne formy podmiotowości. „Teatr okrucieństwa” stanowi więc sprzeczność samą w sobie, zarówno formalnie, jako określenie, jak i istotowo: nie ma takiego życia, które byłoby w stanie wchłonąć ową antytezę.

To właśnie w tym momencie pojawia się w dyskursie Derridy aporia, rozumiana najpierw technicznie, za Arystotelesem, jako rodzaj sprzeczności, która oprócz tego, że - na zasadzie negatywnej - podlega prawom logiki, ujawnia coś jeszcze, element kluczowy dla zrozumienia dekonstrukcji , czyli czas, który albo przejawia się w procesie odpodmiotowienia, albo poprzez quasi-religijną fantazję o "czasie, który nadchodzi". Aporię można rozumieć w trzech porządkach: etymologicznym - jako coś absolutnie nieoczekiwanego, a więc rodzaj zdarzenia, zmieniającego obraz świata, logicznym - jako wewnętrzna antynomia tkwiąca w rozumowaniu, nieprzezwyciężalna trudność polegająca na równoważności sprzecznych rozwiązań, retorycznym - jako teatralizowana w wypowiedzi niemożność orzekania o przedmiotach, przybierająca postać hiperbolicznego wahania między różnymi formami logicznymi i językowymi. Te trzy porządki, z których wyłaniają się temporalne, racjonalne i figuralne własności dekonstrukcji, stały się niemal dogmatami i odsłaniają dziś słabość projektu Derridy, ale zarazem, paradoksalnie, dają szansę na "wyobrażenie sobie” innej rozumności "po dekonstrukcji". Aporia jest swego rodzaju nerwicą dialektyki - nieustannie powtarza, że ze sprzeczności nie ma wyjścia, a każde rozstrzygnięcie jest u podstaw skażone egzystencjalną histerią w stylu Kierkegaarda, dla którego moment decyzji był równy szaleństwu. Ten repetycyjny tok dekonstrukcji opiera się na bardzo silnej presupozycji czasu, urzeczywistniającego się w postaci „odwlekania i różnicowania" - farmakon jest z a ra z e m trucizną i lekarstwem, prawo do śmierci należy ró w no cześn i e do Antygony, jak i Kreona, gościnność jest nie do pomyślenia bez wrogości, świat przybiera kształt widma, dlatego że zarazem jest niematerialnym zjawiskiem, jak i nieobecnym duchem. To tylko niektóre ze słynniejszych przykładów Derridiańskiej aporetyki.

Dekonstrukcja przegrała dlatego, że w dużej mierze unieważniła wywrotowy aspekt myślenia antytetycznego. Co prawda widać w niej wyraźnie rys kryzysowo-krytyczny (każda aporia jest przeciąganym w nieskończoność kryzysem), a także jednostkowy, ale właśnie dlatego, że aporia staje się fetyszem, pustym miejscem w procesie refleksji, owa jednostkowość okazuje się pozorna. Podmiot poznawczy, a więc, wedle Derridy, tropiący w tekstach, systemach, formach politycznych, miejsca nierozstrzygalności, okazuje się podmiotem czerpiącym wtórną rozkosz z nerwicy, w jakiej się pogrąża, powtarzając aporetyczne zaklęcia. Jednostkowości nie da się ocalić wyłącznie za pomocą 
wprawienia w ruch sprzeczności, lecz za cenę straty, jaka zawsze towarzyszy zajęciu konkretnej pozycji. Nie zawsze i nie wszystko, co mówimy i myślimy, podlega, jak chciałby Derrida, performatywnej sile. Nie da się bowiem pomyśleć performatywnego tworzenia i rozsiewania znaczeń bez ich przeciwieństwa: elementarnego doświadczenia utraty znaczenia i pewnych możliwości życia, które wiążą się istnieniem w ramach rzeczywistości symbolicznej - nie ma absolutnej pozycji podmiotowej, która uwzględniałaby każdą sprzeczność życia.

Za koronny przykład tego idealistycznego backlashu może posłużyć drobiazgowa równoległa analiza "rodziny" w dziele Hegla oraz Genetowskich „ceremonii żałobnych" przeprowadzona w Glas. Pisząc "na dwie ręce”, czyli tworząc dwie kolumny na jednej stronie, Derrida staje się tekstowym mistagogiem, mistrzem tkackim, splatającym najdelikatniejsze nici pojęć, figur, skojarzeń, homologii. Jeśli tytułowe „podzwonne” jest słowem-kluczem dla dekonstrukcyjnej „ekonomii śmierci”, to „ceremoniał" procesu myślenia stanowi już tylko retorykę niemożności wyjścia ze stanu żałoby. Ostatecznie nie wiemy, kto w "rodzinie" umarł naprawdę i czy lub dlaczego Antygona została skazana na widmowe istnienie, na czym polega miłosna utrata w dziełach Geneta. Dla Derridy granice dekonstrukcji ostatecznie wyznacza śmierć, jednak nie jednostkowa, ale myślana na modłę Heideggerowskiej amorficznej konieczności, która „luzuje” napięcie, jakie towarzyszy aporii językowej czy egzystencjalnej. Dekonstrukcja, która za egzystencjalny i filozoficzny cel obiera "prze-życie” [sur-vivre], staje się w ten sposób tyleż minimalnym programem dla współczesności, co obsceniczną praktyką, blokującą nowe formy życia oraz rodzące się z nich „inne nauki”. We wstępie do Widm Marksa Derrida, dokonując paralogicznej przewrotki, skazuje nas na tę samą fetyszyzację abstrakcyjnego "pomiędzy”, znów w jego ostatecznej formie - życia i śmierci: „Życie z definicji nie jest czymś, co uczy się samo od siebie - nie jest więc czymś, czego można by się samemu nauczyć. Nie można nauczyć się od siebie samego, od życia i poprzez życia. Jedynie od innego i poprzez śmierć. A w każdym razie od innego na krawędzi życia"122. Postulat „życia w końcu prawdziwego" zostaje zawłaszczony przez ostateczne bezosobowe Widmo, który niczym Duch Ojca w Hamlecie wygrywa starcie ze wszystkim, co zgłasza pretensję do życia na własnych, czyli niespektralnych prawach.

Przypomnijmy sobie w tym kontekście egzystencjalne i artystyczne konsekwencje gestu Artauda. Jego wczesne teksty programowe zostały napisane według wszelkich praw zrozumiałości i komunikatywności, teksty późne to rwane fragmenty, powstałe już w języku stworzonym, sztucznym, niepodobnym do żadnego innego (w stopniu znikomym także do rodzimej francuszczyzny). Ostatecznie owo marzenie o wcieleniu

12 J. Derrida Widma Marksa. Stan długu, praca żałoby i nowa Międzynarodówka, przeł. T. Załuski, PWN, Warszawa 2016, s. 11. 
aporii Artaud zamyka się zarówno, jak chciałby Foucault, w szaleństwie „nieobecności dzieła", czyli milczeniu, lub ucieleśnienia w semiotycznym rytmie artykulacji, jak mówi Kristeva ${ }^{13}$, ale przede wszystkim w rozpaczliwym i dojmującym śladzie pisma, graficznej mowy, która - znów w ramach sprzeczności - stale się wypowiada i ciągle się ucisza. Ten ostatni etap, w którym Artaud w obłędzie próbuje złamanym ołówkiem wyrysować na swoim ciele hieroglify, o których marzył jako młody rewolucjonista teatru, to sytuacja, która bodaj najpełniej określa praktykę dekonstrukcji. Jednak właśnie to, co w tej analizie było niesłychanie intensywne (ruch pojęć i figur, umiejętność określania zmiennej temporalności myślenia), stało się kilkadziesiąt lat później filozoficznym przekleństwem Derridy i jego praktyki dekonstrukcji. Gdy spojrzymy na teksty składające się na książkę do pewnego stopnia programową, czyli Apories, to bez trudu można dostrzec, jak tytułowe określenie, będące wcześniej rozsadnikiem napięć, dzięki któremu można było w dialektycznym geście przechwycić pewne słowa, figury i obrazy, stało się - jako się rzekło - własnym przeciwieństwem: jednorodnym i łatwym w użyciu kategorialnym fetyszem, za pomocą którego opowiada się, ostatecznie, zawsze tę samą historię myślenia ${ }^{14}$. Niezależnie, czy Derrida pisze o uniwersytecie, archiwum, przyjaźni, religii, czy o „uchu Heideggera", dostajemy obraz świata prawdziwie zredukowany i unieruchomiony w aporetycznej niemożności. Jeśli, jak często zwykł mawiać autor Gorq̨czki archiwum, aporia to nieskończony opór i/lub ślad nie do wymazania, to oba jej aspekty, teoretyczny i materialny, istnieją w ramach „złej nieskończoności", która ostatecznie mówi życiu proste "nie".

\section{5.}

Drugim przykładem jest twórczość Rolanda Barthes'a. Jego książki i teksty czytane redukcyjnie, sprowadzane są dziś zazwyczaj - z jednej strony - do dyskursu o przyjemności, z drugiej zaś - do dyskursu o traumie i miłości. Projekt autora Mitologii rozciąga się więc między tymi dwoma biegunami, czyli między doświadczeniową, cielesną i antyteoretyczną wizją lektury, a koncepcją fotografii, w której teoria obrazu i technika jego tworzenia staje się precyzyjnym i w zasadzie systemowym opisem późnonowoczesnej kondycji ludzkiej. Ale istnieje Barthes, którego nie da się sprowadzić do tych dwóch modalności teoretycznych i który - zwłaszcza dziś - jest symptomem

13 Por. M. Foucault Historia szaleństwa w dobie klasycyzmu, przeł. H. Kęszycka, PIW, Warszawa 1987, s. 481-483; J. Kristeva Podmiot w toku, przeł. J. Momro, „Didaskalia” 2008 nr 88.

14 Por. J. Derrida Apories, Galilée, Paris 1996. Ujmując rzecz w ogromnym skrócie, myśl Derridy przechodzi od analizy śmierci u Heideggera, a kończy się na refleksji nad współczesnym marranizmem. 
myślenia wyrastającego z rozpoznania jego antytetycznego charakteru. W ten sposób Barthes, pozostając krytykiem w szerokim sensie tego słowa, mającym zatem własne wyobrażenie zmiany kulturowej, pokazuje, że pojęciowa czy teoretyczna niestabilność stanowi nie tylko oczywisty punkt wyjścia każdej procedury badawczej, ale również łączy ją z określonym doświadczeniem realności. W efekcie inicjalna i prosta sprzeczność między teorią a praktyką przeobraża się u autora Neutrum w mocne związanie założonego programu z nieprzewidywalnością myślenia. Ta szczególność przejawia się niemal w każdym aspekcie refleksji: w procesie pisania, czytania, deszyfrowania, zmysłowego przeżycia oraz rozbijania ideologicznych czy metafizycznych uroszczeń wpisanych w dyskursy.

Bodaj najpełniej widać ten mechanizm „tworzenia poprzez kwestionowanie” w dwóch przypadkach, w których Barthes znakomicie pokazuje nieoczywistą genealogię myślenia o współczesności i teraźniejszości jako problemach poznawczych. W Wyjściach z tekstu przedmiotem refleksji jest krótki, ale gęsty esej antropologiczny Georges'a Bataille'a, Le gros orteil [Paluch] ${ }^{15}$, w którym autor Historii oka przedstawia ludzkie ciało w dwóch przeciwstawnych wariantach ontologicznych: całościowym i uporządkowanym wedle pragmatycznych zasad ewolucyjnej adaptacji i biologicznej funkcjonalności, a więc takim ciele, którego istotą i celem jest życie organiczne, metaboliczne i fizjologiczne (przejawiające się w mechanicznym ujęciu zmysłów), oraz w wariancie amorficznym, czyli bezkształcie [informe], w którym ciało żyje "innym" życiem, niepodlegającym dyskursom, a przede wszystkim praktykom czyniącym z niego przedmiot poznawczej instrumentalizacji. W tym drugim wypadku, od doskonale znanej ekstatycznej i transgresyjnej treści antropologicznej, wynikającej z naruszenia granicy między życiem a śmiercią ${ }^{16}$, istotniejsze okazuje się napięcie, z pozoru mniej atrakcyjne poznawczo, między naturą a kulturą. Bataille, podpowiada Barthes, nie tyle kwestionuje różnicę między "górą" (światem ciała wyprostowanego i rozumnego) a "dołem" (rzeczywistością odrzuconą, brudną, o bezforemnej materialności), nie znosi różnicy między "głową" a „palcem u nogi", lecz dokonuje zasadniczego przesunięcia tego układu. Z tej transpozycji wynikają dwa problemy. Po pierwsze, dla Barthes'a dzieło autora Doświadczenia wewnętrznego nie zamyka się ani w filozofii, ani w mistyce, ani w narracyjnej antropologii, lecz jest w sensie ścisłym myślą heterologiczną. Oznacza to, że nie istnieje dla niej teoretyczny punkt wyjścia (jak słusznie mówi Barthes,

15 Por. R. Barthes Wyjścia z tekstu, przeł. M.P. Markowski, w: tegoż Lektury, przeł. K. Kłosiński, M.P. Markowski, E. Wieleżyńska, Aletheia, Warszawa 2001.

16 Transgresję, której najpełniejszym wyrazem jest przekroczenie seksualne, Bataille definiuje poprzez świadomość, a nie poprzez ciało. Por. G. Bataille Łzy Erosa, przeł. i posłowie T. Swoboda, Gdańsk 2009. 
"«początek» to idea retoryczna"17), bowiem jako refleksja nie jest systemowa ani nie jest myśleniem w kategoriach reprezentacji, lecz stanowi ucieleśnioną i dynamiczną krytykę. Jeśli więc Bataille nie tyle proponuje myślenie „o czymś", ile myślenie "czegoś," to widać jak na dłoni, że życie, doświadczenie oraz pojęcia stanowią złożoną sieć wzajemnych uwikłań, które ukonkretniają moment historyczny. W przypadku eseju Bataille'a moglibyśmy powiedzieć, nie ryzykując wielkiego uproszczenia, że pokazuje on pęknięcie w łonie imperialnego, totalizującego i opresyjnego dyskursu antropologii. „Paluch" to przecież nie tylko figura treści wypartych oraz symbol dyscyplinowanego ciała, lecz także opowieść o tym, jak wszystko to, co „inne" (nienormatywne seksualnie, odmienne rasowo, geograficznie, to, co zwierzęce), stało się kulturowym i intelektualnym odpadkiem, resztką, niepasującą już do żadnego społecznego czy politycznego układu.

Jeszcze wyraźniej widać to miejsce oddziaływania wyobraźni antytetycznej, kiedy Barthes pisze, niemal przez całe swe życie, o teatrze, polityce i koncepcjach wolności Bertolta Brechta ${ }^{\mathbf{1 8}}$. Barthes, w swym najważniejszym z perspektywy doniosłości filozoficznej eseju, pokazuje, w jaki sposób dwie kluczowe kategorie Brechtowskie, czyli "efekt obcości” i „epickość," opierają się na tej samej przesłance krytycznej. Dla autora Baala krytyka jest nie do pomyślenia bez dialektyki, rozumianej tu nie jako pewna technika refleksji, lecz jako niezbywalna właściwość rzeczywistości. Oznacza to, że Brecht traktuje relację między obrazem i dyskursem a światem w kategoriach sprzeczności, będącej zaprzeczeniem reguł reprezentacji. Teatr jest więc miejscem podziału (w obu znaczeniach tego słowa: współuczestnictwa i dzielenia pola zmysłowości) samej materialności życia, a nawet więcej: ekspozycją jego immanencji. To właśnie w niej samej, w jej impasach, przerwach, inkongruencjach powstaje impuls krytyczny, który ma pokazać historyczne warunki powstawania ideologii. Jak trafnie zauważa Barthes, dla Brechta historyczność nie pokrywa się z dyskursywnością, bowiem krytyka ideologii, przemocy i politycznej dominacji nie polega na odsłonięciu „prawdy”, istniejącej za zasłoną pozorów. Autentyczna obecność, będąca na pozór zarazem warunkiem, jak i celem każdego działania scenicznego czy estetycznego, to tylko symulakrum, bezczasowe i fałszywie uniwersalne. Innymi słowy, krytyka staje się dialektyką, nie dlatego, że wszystkiemu nadaje spójność, lecz przeciwnie: dlatego, że niejako „rozpuszcza" formy totalności. Wydaje się jasne, że Barthes chce pokazać „wieczną wywrotowość" teatru, który zrzeka się psychologicznego prawdopodobieństwa i, jako się

R. Barthes Wyjścia z tekstu, s. 106.

18 Por. R. Barthes Brecht i dyskurs: przyczynek do badań nad dyskursywnościq, przeł. K. Kłosiński, w: tegoż Lektury. 
rzekło, przedstawieniowej, a także narracyjnej mocy. Toteż krytyka dyskursu (w tym wypadku teatralnego) jest zarazem dialektyką wyobcowania i życia.

Ale, aby owo życie mogło pojawić się w całej swej intensywności i różnorodności, Brecht wprowadza dwie czasowe modalności. Pierwsza, w ramach której język, słowo, obecność i gest ( $w$ tym oczywiście „metagest", jakim jest „efekt obcości”) są interwencjami w ową ideologiczną spoistość, a więc równocześnie tworzą rozdarcie w obrazie świata. Nie jest to wszakże kategoria negatywna, lecz twórcza, to z niej bowiem rodzi się technika montażu, w którym elementy z różnych, często bardzo odległych od siebie, momentów czy formacji historycznych, wybrzmiewają jako forma aktualności' Ta dialektyka zerwania i zestawiania widoczna jest niemal w każdym dziele Brechta, najwidoczniej może w tych sztukach, w których aspekt pedagogiczny (Lehrstücke) wydaje się mniej wyraźny niż obrazy łączące alegorie Historii z chwilą rewolucyjną lub momentem kryzysowego przesilenia, jak np. w Dobrym człowieku z Seczuanu czy Życiu Galileusza. Drugą modalnością jest retroaktywność, dzięki której Brecht, a za nim Barthes, rezygnuje z telosu zdarzeń, wybierając chwilę przeciwko ciągłości, nawet jeśli miałaby to być ciągłość uzasadniana poniewczasie, tzn. wedle zasady, w której wyobrażony cel pozwala przekroczyć wyjściową poznawczą nierozstrzygalność. Paradoksalnie zatem, jak mówi Barthes, , krytyczna sztuka niczego nie oczekuje, chce być momentalna i powtarzalna: tak samo brzmi właściwa definicja teatru według Brechta. Epickość jest tym, co tnie (nożycami) zasłonę, rozpuszcza zakrzepłą smołę mistyfikacji [...] $]^{\prime 20}$. Owo "cięcie" jest zarazem wyrwą w dominującym porządku poznawczym, w hegemonicznym obrazie świata, który sztuka poddaje dezaktywacji, dzięki czemu odbiorca może rozpoznać własne wyobcowanie w wyobcowaniu drugiego człowieka. Tak też można wytłumaczyć pozycję „zewnętrza”, jaką cyklicznie przyjmują postaci sztuk Brechta - znajdują się na zewnątrz rzeczywistości, z której zostali wyrzuceni, sytuują się na marginesie i odgrywają, jako typy, tragedię oddzielenia: ciała od myślenia, życia od ideologicznej mistyfikacji, refleksji od praktyki. Dla Brechta teatr jest krytycznym laboratorium, w którym zwykle niewidzialne doświadczenia odsłaniają formy najbardziej opresyjne, a przemianie społeczeństwa zawsze towarzyszą nowe, nieprzewidziane formy alienacji ${ }^{\mathbf{2 1}}$. Podstawą jest tu rytmiczny ruch od wyjątku do reguł:

Niech zastanowią was

Szczególnie te zwykłe sprawy.

Por. G. Didi-Huberman Strategie obrazów. Oko historii 1, przeł. ). Margański, Ha!art, Kraków 2011.

R. Barthes Brecht i dyskurs: przyczynek do badań nad dyskursywnością, s. 172.

Por. F. Jameson Brecht and Method, Verso, London-New York, 1998. 
Prosimy was usilnie, nie uważajcie

Rozwijającej się akcji za słuszną,

Bo nie ma nic słusznego

W tych czasach krwawego zamętu,

Uporządkowanego nieładu, planowanego bezprawia,

Odczłowieczonej ludzkości, aby z wymienionych spraw

Żadna nie pozostała niezmienna. ${ }^{22}$

Opisane powyżej dwa ujęcia problemu antytezy wiążą się, jako się rzekło, z kwestią wyobraźni pojmowaną jako krytyczny schemat poznawczy, który w dużym stopniu określa dyskursy i praktyki życia nowoczesnego. Dekonstrukcja jako forma myśli spekulatywnej przyjęła jako warunek równoczesnej możliwości i niemożliwości skrajną formą antytezy, czyli aporię. Jednak aporia, która jest pojęciowym odpowiednikiem fizjologicznego mechanizmu powstawania „ślepej plamki", a więc miejscem niewidoczności, poza ludzkim polem widzenia, stała się automatyzmem i gestem niekrytycznym właśnie dlatego, że - z definicji - zatrzymała wyobraźnię "zawsze w tym samym” miejscu nierozstrzygalności. Z kolei przykład Barthes'a, zdawałoby się o wiele bardziej odległego od naszych czasów, pokazuje dobitnie, że wyobraźnia antynomiczna nie zawsze działa tak samo, że jest roszczeniem do heterologicznej prawdy rozumu. To właśnie Bataille i Brecht, ich pozornie nieprzystające do siebie dzieła, stają się patronami sprzeczności, stanowiącej nie tyle przeszkodę epistemologiczną i społeczną, zapowiadającej nieodwołalne zerwanie lub ucieczkę w regresję, lecz dialektykę teraźniejszości²3. Antytetyczność nie jest punktem wyjścia ani miejscem kresu teorii czy filozofii, ani nawet formą przyszłości, lecz kształtem a ktualności - nie da się jej usunąć, ale należy ją przekroczyć.

\section{6.}

W istocie szkice, recenzje i przyczynki tworzące niniejszy numer „Tekstów Drugich"stanowią rodzaj humanistycznych inwencji. Zarówno w znaczeniu wynajdywania czegoś nowego, jak i w sensie muzycznym - to ćwiczenia z technik myślenia i pisania, a także sposoby wsłuchiwania się w różne „brzmienia" pozornie tożsamych i nienaruszalnych tekstów, pojęć, prawd, ukrytych za powłoką naukowych czy społecznych fantazmatów.

B. Brecht Wyjątek i reguła, przeł. B. Witek-Swinarska, w: tegoż Dramaty, t. 1, wyb. i wstęp. R. Szydłowski, posł. A. Wirth, PIW, Warszawa 1962, s. 147.

23 Por. P. Virno Le souvenir du présent. Essai sur le temps historique, trad. M. Valensi, L'Eclat, 1999, zwł. cz. II: Temporalité de la puissance, Pontentialité du temps. 
Toteż wśród tekstowych różności znajduje się esej Weroniki Szulik poświęcony refleksji filmoznawczej Karola Irzykowskiego. Irzykowski pasjonat X Muzy to zjawisko wyjątkowe w naszej kulturze, a jego pomysły można z pożytkiem rozpatrywać w kontekście tej części estetyki kina światowego, dla której kino należy nie tylko do sfery przemysłu kulturowego, ale przede wszystkim jest pewną ideą. W kluczu ideologii estetycznych można również potraktować artykuł o zjawisku tyleż literackim, co kulturowym, a nawet politycznym, czyli twórczości Boba Dylana, wokół której rozgorzał spór po przyznaniu mu Nagrody Nobla. Innym silnie obecnym dziś fenomenem, łączącym pozornie odmienne dyskursy, są rozmaite teorie przestrzeni: od usankcjonowanej już refleksji nad geopoetyką (prezentowanej w numerze przez Andrzeja Niewiadomskiego), przez rewizję myślenia o pograniczu (esej Ingi Iwasiów o Oksanie Włodzimierza Odojewskiego), po medytację nad możliwością użycia antycznej kategorii chory do analizy współczesnych praktyk ruchu. Splot inwencji i wyobraźni pojawia się w szkicach dotyczących spraw niezwykłości, dziwności, marzenia sennego i mechanizmów wyparcia we współczesnej kulturze. Jak głosi tytuł artykułu Krzysztofa Brenskotta, celem takich badań jest "oswojenie historii", konfrontacja z potwornością naszych fantazji. Stąd teksty o tak pozornie odległych zjawiskach: z jednej strony o znakomitym serialu StrangerThings, z drugiej - o demonologii ludowej. Ożywcze sprzeczności pozwalają dostrzec w intermedialności reportażu (Edyta Żyrek) problemy ze statusem faktu i technik medialnych, zaś w ekfrazie (Rozalia Słodczyk) współczesne dylematy z heterogenicznością i transmisją tekstów kultury.

Wydaje się jednak, że problemem najciekawszym jest nieoczekiwana fuzja wyobraźni, pracy oraz zmiany społecznej. Widać to doskonale w dwóch tekstach. W swej brawurowej recenzji ze świetnej książki Michała Gusina o Lacanie „filozoficznym"24 Anna Turczyn zadaje klasyczne już pytanie o to, dlaczego nie ma w Polsce psychoanalizy. Odpowiedź autorki pokazuje konieczność przemyślenia psychoanalizy jako pracy i praktyki, a nie apriorycznej formy refleksji: zarówno terapii, jak i myślenia. Działanie symptomów, mówi autorka, możliwe jest tylko pod warunkiem pracy przeniesienia, a więc leczącego mówienia. To ono pozwala dojść do miejsca, w którym pacjent uznaje własną skończoność - i może zacząć żyć. Podobnie nieredukcyjny, ale krytyczny, a nawet wywrotowy charakter ma studium Marcina Kościelniaka o pierwszej Solidarności, w którym imponująca praca materiałowa łączy się z diagnozą dzisiejszego społeczeństwa. Kościelniak uprawia genealogię historii przemilczanej, tłumionej, wykluczanej; pisze (nie on pierwszy, ale na pewno inaczej) o kobietach zaangażowanych w ruch społeczny, w którym brutalny patriarchat bierze swój początek z opresji Kościoła

24 Por. M. Gusin Symptomy psychoanalizy. Jacques Lacan: od filozofii do antyfilozofii, Universitas, Kraków 2018. 
Katolickiego, tyleż w wydaniu praktycznego przymusu wobec kobiet, co habitusu, w którym, chcąc nie chcąc, żyjemy i dzisiaj. Jak widać, wyobraźnia wychodząca ze sprzeczności ma swoją przyszłość, albo inaczej: wyobraźnia antytetyczna pozwala na krytykę świata, który znamy. Być może właśnie z tego impulsu "wyobrażania sobie” zrodzi się pragnienie „innej” emancypacji, „innej” współczesności, ,innego” myślenia.

\section{Abstract}

\section{Jakub Momro}

JAGIELLONIAN UNIVERSITY (CRACOW)

The Antinomical Imagination

Momro outlines a paradigm that is key in contemporary thought, namely dialectics, which needs to be developed as much as it needs to be revised and updated. The dialectics of both mental concepts and practices (practical theory) no longer falls into the tradition of idealistic practical philosophy but into the mode of subjectivity and history understood in materialistic terms. This important type of critical imagination allows us to treat the principle of antithetical modernity as a dynamic of opening up and engagement, which boils down to a utopia of the present. The dialectical imagination also enables a critique of the rules by which discourses are validated - rules based on simply negating any antithetical language (cf. Bruno Latour). At the same time, Momro critiques projects based on the fetishism of contradiction (Derrida's deconstruction). He not only examines the current achievements in the humanities but he also outlines an epistemological imagination that would allow us not only to think freedom but also to experience it.

\section{Keywords}

imagination, contradiction, aporia, dialectics, utopia, present 